\title{
Relationship between body composition and level of physical activity among university students
}

\author{
Relación entre la composición corporal \\ y nivel de actividad física en \\ estudiantes universitarios
}

\begin{abstract}
Introduction: the body composition and lifestyle of university students are influenced by behavioral, psychological, socioeconomic and cultural factors. Objective: to analyze body composition and its correlation with lifestyle in a sample of university students in the health area living at the Ribeirao Preto Campus of the University of São Paulo (USP). Methodology: a cross-sectional study was conducted on 501 students enrolled in USP courses of the Ribeirao Preto Campus. Weight and height were measured and body composition was determined by bioelectrical impedance. The short version of the International Physical Activity Questionnaire (IPAQ) was then applied. Results: The sample predominantly consisted of females (73.05\%), with $26.95 \%$ males. The averages of age, weight, stature body mass index (BMI), total fat mass and fat-free mass were $20.4 \pm 2.8$ years, $63.0 \pm 13.5$ $\mathrm{kg}, 166.9 \pm 9.0 \mathrm{~cm}, 22.4 \pm 3.4 \mathrm{~kg} / \mathrm{m}^{2}, 24.0 \pm 7.5 \%, 45.3 \pm 10.3 \mathrm{~kg}$, respectively. Although almost $70 \%$ of the students were in the normal BMI range, $70.8 \%$ of them had high levels of fat mass. According to IPAQ, the individuals were classified as sedentary $(10.2 \%)$, irregularly active $(39.3 \%)$, active $(42.1 \%)$, and very active (8.4\%). Conclusions: Most of the university students studied were classified as being of normal weight according to the BMI, but the high levels of body fat mass detected should not be overlooked. In addition, even though most of the sample was considered to be active, according to the IPAQ, it can be seen that practically half the students (49.5\%) were irregularly active or sedentary.

Keywords: body composition, physical activity, electrical bioimpedance, university students, body mass index.
\end{abstract}

\section{INTRODUCTION}

Obesity is defined as abnormal and excessive fat accumulation in adipose tissue [1] that adversely affects the health of an individual, being considered a risk factor for diseases such as hypertension, type 2 diabetes, dyslipidemia, metabolic syndrome, heart disease, and certain types of cancer [2-9], and representing a public health problem the world over [10-12], also among adolescents and young adults [13-15].

Diets with a high energy intensity and the reduction of energy expenditure due to a sedentary lifestyle are factors associated with the occurrence of obesity [16] and it has recently been observed that weight gain and the higher pre-
Mirele Savegnago Mialich

Nayara Covolo

Josiane Cheli Vettori

Alceu Afonso Jordao Junior

Department of Internal Medicine, Faculty of Medicine of Ribeirao Preto, University of Sao Paulo. Ribeirao Preto, SP, Brazil.

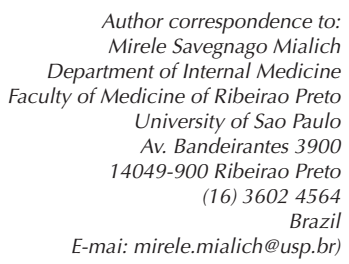

Author correspondence to: Mirele Savegnago Mialich Department of Internal Medicine Faculty of Medicine of Ribeirao Preto University of Sao Paulo Av. Bandeirantes 3900 14049-900 Ribeirao Preto (16) 36024564 Brazil

E-mai:mirele.mialich@usp.br)

Este trabajo fue recibido el 28 de Noviembre de 2013 y aceptado para ser publicado el 18 de Enero de 2014.

valence of overweight and obesity among university students are increasingly frequent and a source of concern for the health system [17].

The index universally accepted for the classification of obesity is the body mass index (BMI) [18]. According to this index, the World Health Organization (WHO) has projected that in 2015 about 2.3 billion people older than 15 years will have excess weight $\left(\mathrm{BMI} \geq 25 \mathrm{~kg} / \mathrm{m}^{2}\right)$ and 700 million will have installed obesity $\left(\mathrm{BMI} \geq 30 \mathrm{~kg} / \mathrm{m}^{2}\right.$ ), representing a $75 \%$ increase in the cases of obesity within 10 years [19]. Studies that have calculated the BMI of university students based on self-reported data have shown that about 27 to $35 \%$ of them 
will be overweight or obese $\left(\mathrm{BMI} \geq 25.0 \mathrm{~kg} / \mathrm{m}^{2}\right)[20,21]$.

Although the $\mathrm{BMI}$ is used all over the world, several authors [22-31] have suggested caution about the exclusive use of this index, since the BMI only considers the weight and height variables, without including others that also influence body composition, such as age, sex, bone structure, and distribution of body fat and fat-free mass. Thus the BMI may possibly generate an equivocal classification of nutritional status and consequent biases in studies that evaluate body composition, as well as delayed or unnecessary health interventions [32].

Once a diagnosis of obesity is established, it becomes more difficult to reverse this condition [33] and there is evidence that, the earlier obesity is installed, the greater the risks of obesity continuing in adult age with its associated comorbidities [21]. A way to control a marked weight gain and the consequent advance of obesity is physical activity [34]. However, Manson et al. [35] observed that a decline in performing physical activity mainly occurs during adolescence among individuals aged 15 to 18 years, and among young adults aged about 20 to 25 years, a period coinciding with an increased tendency to the onset and installation of this disease.

In Brazil, the latest Higher Education Census of 2011 has revealed more than 2 thousand higher education institutions with more than 6.7 million enrolled university students mainly in the age range of 18 to 24 years [36]. A Brazilian study conducted on 281 university students revealed that about $65.5 \%$ of them were sedentary [16].

It should be emphasized that the first experience of freedom and independence without the direct supervision of parents and relatives occurs among young people when they enter the university [37]. These individuals then tend to experience more social and academic pressures aiming at professional success, while contact with different persons in the university context results in self-questioning about values and intrinsic beliefs, possibly provoking a process of modification of habits and lifestyle [38-40].

On this scenario, there is evidence that university students are influenced by the new context they are experiencing, with a consequent change in their previous eating habits and lifestyle which lead to often harmful modifications of their nutritional status involving an increase of overweight, obesity and sedentarism rates [37-40].

On this basis, there is the need for a forceful and precise evaluation of body composition, the practice of physical activity and the factors influencing both aspects in order to contribute to the promotion of health among these individuals. Thus, the objective of the present study was to analyze body composition and its correlation with lifestyle in a sample of university students in the health area living on the Ribeirao Preto Campus of the University of Sao Paulo (USP).

\section{SUBJECTS AND METHODS}

A cross-sectional study was conducted on 501 healthy university students of both genders aged 17 to 30 years, who were duly enrolled in the following graduation courses in the health area of the University of São Paulo (USP) on the Ribeirao Preto Campus, SP: Medicine, Nutrition, Speech Therapy, Biomedical Informatics, Physical Education, and Nursing. The study was approved by the Research Ethics Committee of the University Hospital, Faculty of Medicine of Ribeirao Preto, USP (Protocol no 1955/2010).

The courses were chosen at random and by convenience and all students in a class were invited to participate. The students were first informed about the objectives and methodology of the study and gave written informed consent to participate, being then scheduled for later data collection.

Exclusion criteria were: inability to walk, amputation and the presence of metal objects in the body due to the difficulty in obtaining the measurements or to interference with the results of electrical bioimpedance, and not being enrolled in USP as an undergraduate.

After giving informed consent, all individuals were submitted to measurement of weight and height and to assessment of body composition by bioelectrical impedance. In addition, they all responded to the short version of the International Physical Activity Questionnaire (IPAQ) proposed by the WHO in 1998 [41].

The students were also asked about the places they used for physical activity and about the main reasons that prevented or hindered habitual performance of these activities.

Body weight $(\mathrm{kg})$ was measured with an electronic scale BC-558 Ironman Segmental Body Composition Monitor (Tanita Corp., Tokyo, Japan) with a maximum capacity of $150 \mathrm{~kg}$ and precision of $0.01 \mathrm{~kg}$. For the bioelectrical impedance test, the students were required to have fasted for at least 5 hours, not to have practiced vigorous physical activity in the last 12 hours, to be wearing light clothing, to have abstained from alcoholic or caffeine containing beverages during the 12 hours preceding the exam, and to urinate 30 minutes before the test. Height was measured with a plastic tape attached to a wall with no baseboard, with the student standing barefoot in the orthostatic position with neck and head aligned, with the aid of a wooden bracket. Height ( $m$ ) was measured in duplicate, permitting a maximum variation of $0.5 \mathrm{~cm}$ between the two measures, and the mean value was calculated [42]. BMI was calculated by the equation $\mathrm{BMI}=$ weight $(\mathrm{kg}) / \mathrm{height}(\mathrm{m})^{2}[41]$ and classified according to the criteria proposed by the WHO (1995) [43] as malnutrition (BMI $\left.<18.5 \mathrm{~kg} / \mathrm{m}^{2}\right)$, normal $(18.5$ $\left.\mathrm{kg} / \mathrm{m} 2 £ \mathrm{BMI}<24.9 \mathrm{~kg} / \mathrm{m}^{2}\right)$, overweight $\left(25,0 \mathrm{~kg} / \mathrm{m}^{2} £ \mathrm{BMI}\right.$ $\left.<29.9 \mathrm{~kg} / \mathrm{m}^{2}\right)$ or obesity $\left(\mathrm{BMI} \geq 30.0 \mathrm{~kg} / \mathrm{m}^{2}\right)$.

\section{STATISTICAL ANALYSIS}

Descriptive analysis was performed, with the data reported as total value and percentage (\%). The Student t-test was used to compare two means and analysis of variance (ANOVA) was used to compare three means or more, with the level of significance set at $p<0.05$ in both cases. All analyses were performed with the aid of the Statistical Package for the Social Sciences 15.0. (SPSS).

\section{RESULTS}

Most of the 501 students in the health area were females $(73 \%)$ and mean age was $20.4 \pm 2.8$ years. The variables weight, height, BMI, fat-free mass and total body water were significantly higher among men, with the following values: $71.7 \pm 18.5 \mathrm{~kg}$ and $64.6 \pm 16.0 \mathrm{~kg} ; 169.6 \pm 8.4 \mathrm{~cm}$ and 157.2 $\pm 5.8 \mathrm{~cm} ; 24.4 \pm 3.8 \mathrm{~kg} / \mathrm{m} 2$ and $21.7 \pm 3.0 \mathrm{~kg} / \mathrm{m} 2 ; 60.0 \pm$ $7.7 \mathrm{~kg}$ and $39.8 \pm 3.8 \mathrm{~kg} ; 59.9 \pm 5.3 \%$ and $54.3 \pm 4.4 \%$ for men and women, respectively. As expected, the only variable whose value was higher among women was percent fat mass, which was $26.6 \pm 6.2 \%$ for them versus $17.0 \pm 6.2 \%$ for men.

Stratification of the results according to the various courses revealed that the highest weight and $\mathrm{BMI}$ values were detected in the Physical Education course. This course, together with the Biomedical Informatics and Medicine courses, also presented the highest fat-free mass values, probably due to the fact that most of the subjects in these courses were males, at proportions of $55.93 \%, 65.11 \%$ and $61.29 \%$, respectively. 
Conversely, two courses with higher rates of females (Speech Therapy and Nursing) had the highest fat mass values. These anthropometric and body composition characteristics of the university students according to the courses in which they were enrolled are presented in table1.

The distribution of the university students according to their BMI ranges revealed that about $69.6 \%$ of them were in the normal weight range, as illustrated in figure 1.

Regarding the practice of physical activity, the IPAQ analyzes the pattern of physical activity of an individual, being able to categorize him as sedentary, irregularly active, active, and very active. Using this instrument, it was possible to observe that $10.2 \%$ of the individuals were classified as sedentary, $39.3 \%$ as irregularly active, $42.1 \%$ as active, and $8.4 \%$ as very active. When the physical activity pattern was stratified according to course, the Physiotherapy and Physical Education courses were found to show the lowest sedentarism values among their students ( $2.6 \%$ and $1.6 \%$, respectively), as shown in table 2. It should be emphasized that the curriculum of these two course includes disciplines that stimulate physical activity.

Analysis of body fat content of the university students versus the level of physical activity revealed that, on average, sedentary individuals had higher values of total body fat $(26.56$ $\pm 7.9 \%$ ) and that a low degree of activity was already able to reduce these values in both sexes, as shown in table 3 .

Total percent fat mass was also determined according to $\mathrm{BMI}$ range, revealing relevant discrepancies, since about $20.95 \%$ of the university students $(n=105)$ were categorized as malnourished and of normal weight according to BMI even though they had high values (20 to $24.4 \%$ ) of total fat mass. Also, curiously, 166 other students (33.13\% of the sample) classified as malnourished and normal weight on the basis of the BMI, had very high total body fat values (above 25\%) (table 4).

When asked about the main places they used to perform physical activity (figure 2), $23.5 \%$ of the subjects stated that they used the Center of Physical Education, Sports and recreation (CEFER) of the university itself, revealing the importance of such a center for the execution of these activities. The students also mentioned the use of public places (20.2\%), fitness centers $(19,6 \%)$, courts or fields $(6.4 \%)$, swimming pools $(2.1 \%)$, and their own residence $(0.5 \%)$.

The university students also revealed that the most relevant factors accounting for failure to perform regular physical activity were mainly lack of time (49.3\%), followed by lack of willingness $(17 \%)$, as illustrated in figure 3 , aspects possibly related to the extensive academic workload of the students.

\section{DISCUSSION}

The present study revealed that, even though $70 \%$ of the university students studied were in the BMI range of normal weight, $70.8 \%$ had high fat mass levels, i.e., total body fat rates of $20 \%$ or more, with the cut-off points recommended by the WHO being 25\% for men and 35\% for women [44]. In addition, about half the study population (49.5\%) was sedentary or irregularly active.

\section{TABLE1}

Characterization of the sample as a whole and according to course.

\begin{tabular}{|c|c|c|c|c|c|c|c|c|}
\hline & $\begin{array}{c}\text { Sex } \\
(F / M)\end{array}$ & $\begin{array}{l}\text { Age } \\
\text { (years) }\end{array}$ & $\begin{array}{l}\text { Weight } \\
(\mathrm{kg})\end{array}$ & $\begin{array}{l}\text { Height } \\
(\mathrm{cm})\end{array}$ & $\begin{array}{c}\mathrm{BMI} \\
\left(\mathrm{kg} / \mathrm{m}^{2}\right)\end{array}$ & $\begin{array}{l}\text { Fat-free mass } \\
\qquad(\mathrm{kg})\end{array}$ & $\begin{array}{c}\text { Fat mass } \\
(\%)\end{array}$ & $\begin{array}{c}\text { Total body water } \\
(\%)\end{array}$ \\
\hline $\begin{array}{l}\text { Medicine } \\
(n=62)\end{array}$ & $24 / 38$ & $20.7 \pm 2.1$ & $68.7 \pm 17.3$ & $171.3 \pm 9.7$ & $23.2 \pm 4.1$ & $52.0 \pm 12.1$ & $19.8 \pm 7.3$ & $58.2 \pm 5.4$ \\
\hline $\begin{array}{l}\text { Nutrition } \\
(n=98)\end{array}$ & $86 / 12$ & $20.1 \pm 1.9$ & $59.6 \pm 10.5$ & $166.3 \pm 7.2$ & $21.5 \pm 2.9$ & $43.0 \pm 8.1$ & $24.2 \pm 6.6$ & $55.9 \pm 4.7$ \\
\hline $\begin{array}{l}\text { Speech therapy } \\
(n=44)\end{array}$ & $42 / 2$ & $19.8 \pm 2.0$ & $58.4 \pm 8.4$ & $162.9 \pm 6.2$ & $21.9 \pm 2.4$ & $40.1 \pm 4.9$ & $27.1 \pm 6.4$ & $53.9 \pm 4.5$ \\
\hline $\begin{array}{l}\text { Physiotherapy } \\
(n=75)\end{array}$ & $65 / 10$ & $20.5 \pm 2.1$ & $60.0 \pm 11.7$ & $163.9 \pm 8.3$ & $22.2 \pm 3.2$ & $42.7 \pm 8.4$ & $24.3 \pm 6.3$ & $55.8 \pm 4.4$ \\
\hline $\begin{array}{l}\text { Occupational } \\
\text { therapy } \\
(n=27)\end{array}$ & $26 / 1$ & $20.7 \pm 6.3$ & $54.3 \pm 6.9$ & $160.3 \pm 5.9$ & $21.2 \pm 2.7$ & $38.0 \pm 2.4$ & $25.6 \pm 6.3$ & $55.0 \pm 4.8$ \\
\hline $\begin{array}{l}\text { Biomedical } \\
\text { informatics } \\
(n=43)\end{array}$ & $15 / 28$ & $19.9 \pm 2.4$ & $69.3 \pm 16.4$ & $173.3 \pm 9.2$ & $22.9 \pm 4.1$ & $52.5 \pm 12.9$ & $20.4 \pm 7.6$ & $58.2 \pm 5.6$ \\
\hline $\begin{array}{l}\text { Physical } \\
\text { education } \\
(n=59)\end{array}$ & $26 / 33$ & $20.7 \pm 4.1$ & $71.1 \pm 12.7$ & $172.1 \pm 9.4$ & $23.9 \pm 2.8$ & $52.2 \pm 10.9$ & $22.8 \pm 7.5$ & $56.5 \pm 5.6$ \\
\hline $\begin{array}{l}\text { Nursing } \\
(n=93)\end{array}$ & $82 / 11$ & $20.9 \pm 2.7$ & $61.6 \pm 12.8$ & $164.5 \pm 8.0$ & $22.7 \pm 4.0$ & $42.2 \pm 7.7$ & $26.8 \pm 8.4$ & $53.9 \pm 5.5$ \\
\hline $\begin{array}{l}\text { All courses } \\
(n=501)\end{array}$ & $366 / 135$ & $20.4 \pm 2.8$ & $63.0 \pm 13.5$ & $166.9 \pm 9.0$ & $22.4 \pm 3.4$ & $45.3 \pm 10.3$ & $24.0 \pm 7.5$ & $53.9 \pm 5.5$ \\
\hline
\end{tabular}




\section{FIGURE 1}

Classification of the individuals according to body mass index and gender.

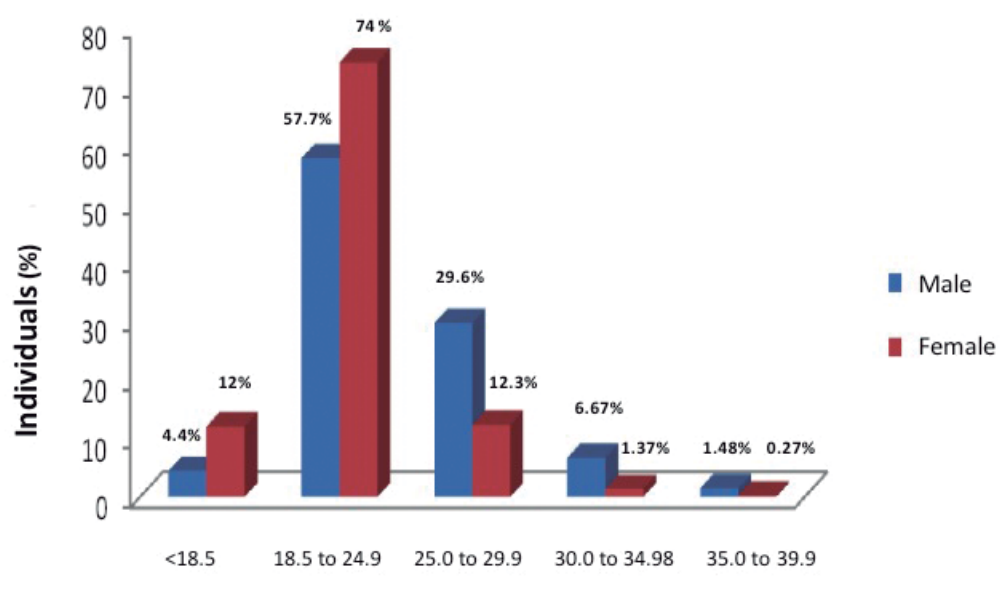

BMI ranges $\left(\mathrm{Kg} / \mathrm{m}^{2}\right)$

\section{TABLE 2}

Classification of the individuals according to pattern of physical activity determined by application of the IPAQ and according to graduation course.

\begin{tabular}{|c|c|c|c|c|c|c|c|c|c|c|}
\hline \multirow[t]{2}{*}{ Courses } & \multicolumn{2}{|c|}{ Sedentarism } & \multicolumn{2}{|c|}{ Irregularly active } & \multicolumn{2}{|c|}{ Active } & \multicolumn{2}{|c|}{ Very active } & \multicolumn{2}{|c|}{ Total } \\
\hline & $\mathrm{n}$ & $\%$ & $n$ & $\%$ & $\mathrm{n}$ & $\%$ & $\mathrm{n}$ & $\%$ & $n$ & $\%$ \\
\hline Medicine & 12 & 19.3 & 21 & 33.8 & 19 & 30.6 & 10 & 16.1 & 62 & 12.4 \\
\hline Nutrition & 4 & 4.0 & 40 & 40.8 & 46 & 46.9 & 8 & 8.1 & 98 & 19.6 \\
\hline Speech therapy & 5 & 11.3 & 22 & 50.0 & 16 & 36.3 & 1 & 2.2 & 44 & 8.8 \\
\hline Physiotherapy & 2 & 2.6 & 31 & 41. 3 & 37 & 49.3 & 5 & 6.6 & 75 & 15.0 \\
\hline Occupational Therapy & 4 & 14.8 & 16 & 59.2 & 6 & 22.2 & 1 & 3.7 & 27 & 5.3 \\
\hline Biomedical Inf. & 3 & 6.9 & 20 & 46.5 & 16 & 37.2 & 4 & 9.3 & 43 & 8.6 \\
\hline Physical education & 1 & 1.6 & 8 & 13.5 & 41 & 69.5 & 9 & 15.2 & 59 & 11.8 \\
\hline Nursing & 20 & 21.5 & 38 & 40.8 & 31 & 33.3 & 4 & 4.3 & 93 & 18.5 \\
\hline Total & 51 & 10.1 & 196 & 39.1 & 212 & 42.3 & 42 & 8.3 & 501 & 100 \\
\hline
\end{tabular}

TABLE 3

Characteristics of body fat of the university students according to their classification based on the short version of the IPAQ.

\begin{tabular}{|c|c|c|c|c|}
\hline & \multicolumn{3}{|c|}{ Mean fat mass (\%) } & \multirow[b]{2}{*}{ P value } \\
\hline & All & Males & Females & \\
\hline Sedentary & $26.56 \pm 7.9$ & $19.8 \pm 6$ & $28.2 \pm 7.6$ & $<0.0001$ \\
\hline Irregularly active & $24.7 \pm 6.7$ & $18 \pm 7.4$ & $26 \pm 5.8$ & $<0.0001$ \\
\hline Active & $23.7 \pm 7.4$ & $17.1 \pm 5.3$ & $26.8 \pm 6.2$ & $<0.0001$ \\
\hline Very active & $17.9 \pm 7.6$ & $14.1 \pm 6.4$ & $25.8 \pm 6$ & $<0.0001$ \\
\hline
\end{tabular}


High prevalence of normal weight according to the BMI have also been detected in other studies [45-47] on large samples ( $N=220,989$, and 4609 students, respectively), ranging from $56.62 \%$ to approximately $65 \%$.

Analysis of the BMI of the women studied here revealed percentages of underweight, normal weight and excess weight individuals similar to those detected in the study by Marcondelli et al. [16], whereas higher percentages of overweight and obese male students were detected in the present study $(37.75 \%)$. This finding may be related to the fact that the courses containing a greater proportion of males (Medicine, Biomedical Informatics and Physical Education) also involved higher levels of physical activity, resulting in high rates of fatfree mass and in high weight and $\mathrm{BMI}$ values characterizing a supposedly more athletic body profile of this population.

The body composition data were found to be compatible with those reported by Heydari et al. [48], since men had a higher BMI and fat-free mass but a significantly lower fat mass than women, in agreement with a physical activity pattern characterized by greater sedentarism among females (28.2 \pm 7.6$)$ than males (19.8 \pm 7.6$)$.

A relevant aspect was that our study was not the only one to reveal a prevalence of normal weight according to $\mathrm{BMI}$ classification conflicting with high levels of body fat (according to percent body fat). Al-Rethaiaa et al. [49] also detected that, even though $57.4 \%$ of their sample of 357 university students were of normal weight according to the BMI, more than 55\% had high or very high levels of total body fat. In addition, they observed that these levels of body fat exceeded normal limits not only in all overweight and obese individuals, but also in $30.7 \%$ of those with a normal BMI.

These data represent a warning sign, since the underestimate of overweight and obesity, especially among young adults with normal BMI, may conceal current and future health problems associated with adipose tissue, leading to erroneous conclusions about the body composition and nutritional and health status of these individuals [50].

Regarding the pattern of physical activity, $10,2 \%$ of the students studied here were sedentary and 39,3\% were irregularly active. These results are alarming, also considering that

TABLE 4

Prevalence of obesity based on the ranges of BMI classification and the percentages of fat mass.

\begin{tabular}{|c|c|c|c|c|c|}
\hline \multirow[t]{2}{*}{$\mathrm{BMI}$ ranges } & \multicolumn{4}{|c|}{ Fat mass (\%) } & \multirow[t]{2}{*}{ Total (\%) } \\
\hline & $\begin{array}{l}\text { Low } \\
(<8)\end{array}$ & $\begin{array}{l}\text { Normal } \\
(8-19.9)\end{array}$ & $\begin{array}{c}\text { High } \\
(20-24.4)\end{array}$ & $\begin{array}{l}\text { Very high } \\
\quad(\geq 25)\end{array}$ & \\
\hline Malnutrition & $N=3(0.6 \%)$ & $\mathrm{N}=26(5.2 \%)$ & $\mathrm{N}=19(3.8 \%)$ & $\mathrm{N}=2(0.4 \%)$ & $\mathrm{N}=50(10.0 \%)$ \\
\hline Normal weight & $\mathrm{N}=10(2.0 \%)$ & $N=89(17.8 \%)$ & $\mathrm{N}=86(17.1 \%)$ & $\mathrm{N}=164(32.7 \%)$ & $N=349(69.6 \%)$ \\
\hline Overweight & $\mathrm{N}=0(0.0 \%)$ & $\mathrm{N}=19(3.8 \%)$ & $N=15(3.0 \%)$ & $\mathrm{N}=51(10.2 \%)$ & $\mathrm{N}=85(17.0 \%)$ \\
\hline Obesity & $\mathrm{N}=0(0.0 \%)$ & $\mathrm{N}=0(0.0 \%)$ & $\mathrm{N}=3(0.6 \%)$ & $\mathrm{N}=14(2.8 \%)$ & $\mathrm{N}=17(3.4 \%)$ \\
\hline Total (\%) & $\mathrm{N}=13(2.6 \%)$ & $\mathrm{N}=134(26.8 \%)$ & $N=123(24.5 \%)$ & $\mathrm{N}=231(46.1 \%)$ & $N=501(100 \%)$ \\
\hline
\end{tabular}

\section{FIGURE 2}

Places for physical activity mentioned by the university students in the health area of USP-RP.

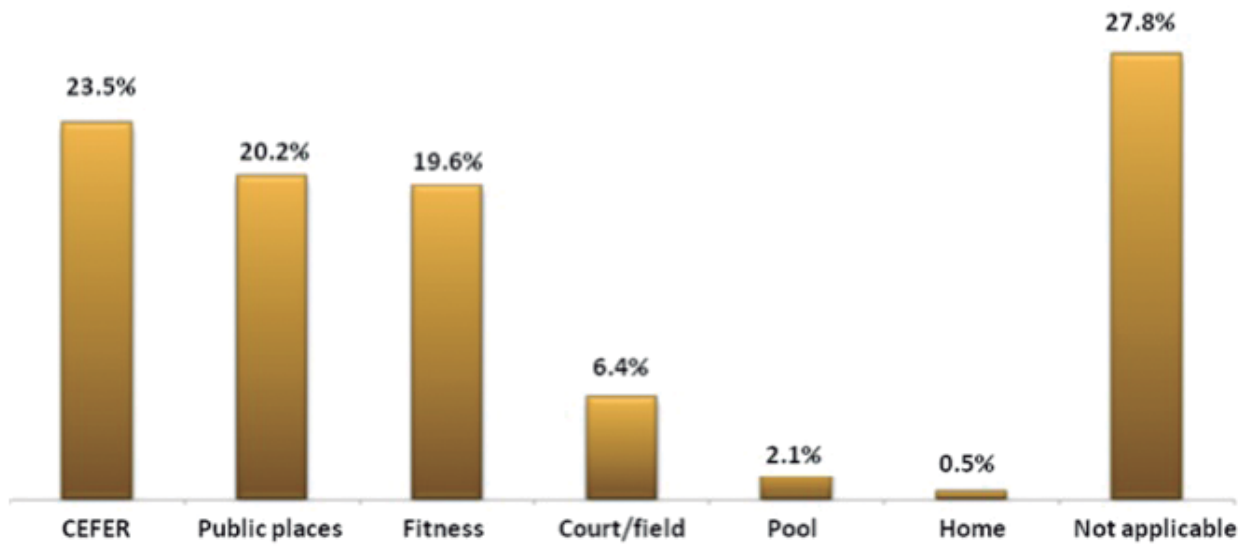


literature data indicate that almost half of all college students in the United States report a reduction of physical activity after the beginning of their undergraduate studies [51].

A Brazilian study [16] detected a high level of sedentarism (65.5\%) among students in the health area. A high level of sedentarism was also observed in a study on college students in the United States [52], indicating that $46 \%$ of them were inactive or exercised irregularly. A 2005 meta-analysis [53] revealed that about 40 to $50 \%$ of American students were physically inactive and that about 30 to $50 \%$ of college students did not engage in levels of physical activity sufficient to generate health benefits.

It should be pointed out, however, that, as also observed in another study on university students in the health area [16], the lowest percentages of sedentarism were detected among Physical Education students, for whom the practice of physical exercise is part of the curriculum.

In the present study, many students used the CEFER (23.5\%) of the university itself as a place for physical activity, underscoring the essential role of the university for the encouragement, achievement and maintenance of life habits that will generate well-being and health benefits for the students. However, when the students were asked about the factors that limited the regular practice of physical activity, the main aspects reported were lack of time (49.3\%) and of willingness (17\%). Marcondelli et al. [16] also detected lack of time as a factor preventing physical activity, as well as the lack of financial resources, which was mentioned by $5.55 \%$ of the students in the present study.

The present study has limitations since a validated questionnaire was not used to assess the real relevance and impact of the factors that limit the regular practice of physical activity among university students on their health status and on the generation of possible associated comorbidities.

However, the results obtained lead us to reflect about how the life habits of university students are vulnerable and very important. This may be related to the challenging transition from adolescence to emerging adult age and to the increased responsibilities and independence often experienced by students entering the university. Thus, while these young people experience independence and become responsible for their own choices, this acquired independence may involve the acquisition of inappropriate dietary, lifestyle and physical activity choices, with future impairment of the health and well-being of these individuals [52-58]. This scenario becomes even more serious with respect to university students in the health area who, in turn, will be multipliers of good health habits in various populations within the ambit of their professional activity.

\section{CONCLUSIONS}

The present study examined the health habits of university students based on all the contextual factors that arise during the graduation period and permitted us to identify the nutritional and body composition profile and the pattern of physical activity of the students. A high prevalence of irregular practice of physical activity was detected, associated with high levels of body fat even among individuals whose BMI was in the normal range.

In this respect, the graduation period represents a time of change in the life of a student, with greater propensity to the acquisition of habits that may have repercussions throughout adult life. Thus, the universities count on a structural and organizational condition that can be used to promote health and healthy habits, contributing to the formation of conscious individuals aware of the importance and impact of these habits on their own health and well-being as well as those of the population they will serve as health professionals.

\section{RESUMEN}

Introducción: la composición corporal y el estilo de vida de los estudiantes universitarios se ven influidos por factores conductuales, psicológicos, socioeconómicos y culturales. Objetivo: analizar la composición corporal y su correlación con

\section{FIGURE 3}

Reported reasons contributing to the lack of physical exercise among university students in the health area of USP-RP.

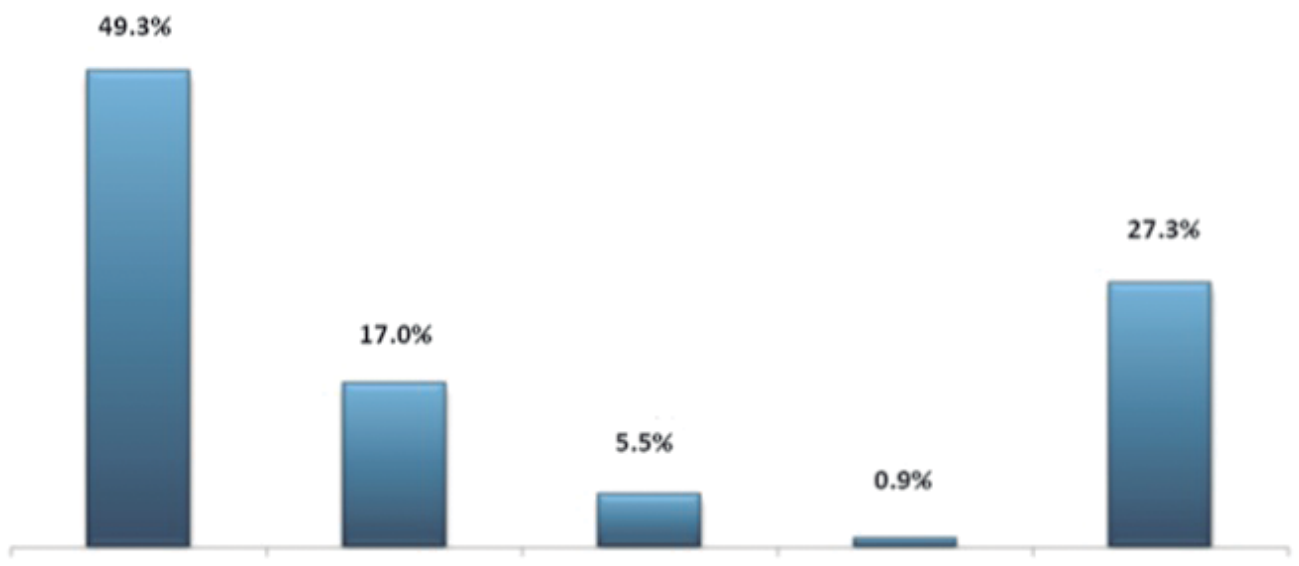

Lack of time

Lack of willingness Financial situation

Never thought about this

Not applicable 
el estilo de vida en una muestra de estudiantes universitarios del área de la salud que viven en el campus de Ribeirao Preto de la Universidad de São Paulo (USP). Metodología: estudio transversal que se llevó a cabo en 501 estudiantes matriculados en los cursos del Campus USP Ribeirão Preto. El peso y la talla se midieron y la composición corporal se determinó mediante impedancia bioeléctrica. A continuación, se aplicó la versión corta de la International Physical Activity Questionnaire (IPAQ). Resultados: La muestra consistió predominantemente de mujeres $(73,05 \%)$, con $26,95 \%$ de hombres. Los promedios de edad, peso, índice de masa corporal (IMC), la masa grasa total y la masa libre de grasa fueron $20,4 \pm 2,8$ años, 63,0 $\pm 13,5 \mathrm{~kg}, 166,9 \pm 9,0 \mathrm{~cm}, 22,4 \pm 3,4 \mathrm{~kg} / \mathrm{m}^{2}, 24,0 \pm 7,5 \%$, $45,3 \pm 10,3 \mathrm{~kg}$, respectivamente. Aunque cerca del $70 \%$ de los estudiantes estaban en el rango normal de IMC, 70,8\% tenían altos niveles de masa grasa. Según IPAQ, los individuos fueron clasificados como sedentarios (10,2\%), irregularmente activos $(39,3 \%)$, activos $(42,1 \%)$, y muy activos $(8,4 \%)$. Conclusiones: La mayoría de los estudiantes universitarios estudiados fueron clasificados como de peso normal de acuerdo con el índice de masa corporal, pero los altos niveles de masa grasa corporal detectada no deben pasarse por alto. Además, a pesar de que la mayor parte de la muestra se considera activo, de acuerdo con la IPAQ, se puede ver que prácticamente la mitad de los estudiantes $(49,5 \%)$ eran de forma irregular activos o sedentarios.

Palabras clave: composición corporal, actividad física, bioimpedancia eléctrica, estudiantes universitarios, Indice de Masa Corporal.

\section{REFERENCES}

1. World Health Organization: Obesity: preventing and managing the global epidemic. Report of a WHO consultation. [http://whqlibdoc.who.int/trs/WHO_TRS_894. pdf]. World Health Organ Tech Rep Ser. 2000, 894:1-253. (accessed September 20, 2013)

2. Yang $P$, Zhou $Y$, Chen B, Wan HW, Jia GQ, Bai $H L, W u$ $X T$ : Overweight, obesity and gastric cancer risk: Results from a meta-analysis of cohort studies. Eur J Cancer 2009; 45(16): 2867-73.

3. Freedland SJ, Wen J, Wuerstle M, Shah A, Lai D, Moalej B, Atala C, Aronson WJ: Obesity is a significant risk factor for prostate cancer at the time of biopsy. Urology 2008; 72: 1102-5.

4. Nguyen NT, Magno CP, Lane KT, Hinojosa MW, Lane JS. Association of hypertension, diabetes, dyslipidemia, and metabolic syndrome with obesity: Findings from the National Health and Nutrition Examination Survey, 1999 to 2004. J Am Coll Surg 2008; 207: 928-34.

5. Abbasi F, Brown BW, Lamendola C, McLaughlin T, Reaven $G M$. Relationship between obesity, insulin resistance, and coronary heart disease risk. J Am Coll Cardiol 2002; 40: 937-43.

6. Flegal KM, Carroll MD, Kit BK, and Ogden CL. Prevalence of obesity and trends in the distribution of body mass index among US adults, 1999-2010, J Am Med Assoc. 2012; 307: 491-7.

7. Hubert HB, Feinleib M, McNamara PM, Castelli WP. Obesity as an independent risk factor for cardiovascular disease: a 26-year follow-up of participants in the Framingham Heart Study. Circulation 1983; 67(5): 968-77.

8. Peppard PE, Young T, Palta M, Dempsey J, Skatrud J. Longitudinal study of moderate weight change and sleepdisordered breathing. JAMA 2000; 284 (23): 3015-21.

9. Carpenter CL, Bernstein L. Obesity and cancer risk.
In: Nutritional Oncology. Heber D, Blackburn G, Go VL Milner J, Eds. Academic Press, Burlington, Mass, USA, 2nd edition, 2006.

10. Ogden CL, Carroll MD, Kit BK, Flegal KM. Prevalence of obesity and trends in body mass index among US children and adolescents, 1999-2010. JAMA 2012; 307 (5): 483-90.

11. Roger VL, Go AS, Lloyd-Jones DM, Benjamin EJ, Berry JD, Borden WB et al. Executive summary. Heart Disease and Stroke Statistics - 2012 Update. A report from the American Heart Association. Circulation 2012; 125 (1): 188-97.

12. Berghofer A, Pischon T, Reinhold T, Apovian CM, Sharma AM, Willich SN. Obesity prevalence from a European perspective. A systematic review. BMC Public Health 2008; 8: 1-10.

13. Carnethon MR, Gidding SS, Nehgme R, Sidney $S$, Jacobs $D R J r$, and Liu K. Cardiorespiratory fitness in young adulthood and the development of cardiovascular disease risk factors. JAMA 2003; 290: 3092-100.

14. Kimm SY, Glynn NW, Obarzanek E, Kriska AM, Daniels $S R$, Barton BA, and Liu K. Relation between the changes in physical activity and body-mass index during adolescence: a multicentre longitudinal study. Lancet 2005; 366: 301-7.

15. Palaniappan L, Carnethon MR, Wang Y, Hanley AJG, Fortmann SP, Haffner SM, and Wagenknecht L. Predictors of the incident metabolic syndrome in adults: the Insulin Resistance Atherosclerosis Study. Diabetes Care 2004; 27: 788-93.

16. Marcondelli P, Costa THM, Schmitz BAS. Nível de atividade física e hábitos alimentares de universitários do $3^{\circ}$ ao $5^{\circ}$ semestres da área da saúde. Rev Nutr 2008; 21(1): 39-47.

17. Greene GW, Schembre SM, White AA, Hoerr SL, Lohse $B$, ShoffS, Horacek T, Riebe D, Patterson J, Phillips BW, Kattelmann KK, Blissmer B. Identifying clusters of college students at elevated health risk based on eating and exercise behaviors and psychosocial determinants of body weight. J Am Diet Assoc 2011; 111(3): 394-400.

18. Gibson RS. Nutritional assessment: A laboratory manual. Oxford: Oxford University Press,1993.

19. Associação Brasileira para o Estudo da Obesidade e Síndrome Metabólica (ABESO). Disponível em: http://www. abeso.org.br/. Acessado em 22/09/2013

20. Huang TT, Harris KJ, Lee RE, Nazir N, Born W, Kaur H: Assessing overweight, obesity, diet, and physical activity in college students. J Am Coll Health 2003; 52: 83- 6.

21. Lowry R, Galuska DA, Fulton JE, Wechsler H, Kann L, Collins JL. Physical activity, food choice, and weight management goals and practices among U.S. college students. Am J Prev Med 2000; 18: 18- 27.

22. Garn SM, Leonard WR, Hawthorne VM. Three limitations of the body mass index. Am J Clin Nutr. 1986; 44 (6): 996-7.

23. Garrow JS. Three limitations of the body mass index. Am J Clin Nutr. 1988; 47: 553-3.

24. Mclaren OS. Three limitations of body mass index. Am J Clin Nutr. 1987; 46: 121.

25. Anjos LA. Índice de massa corporal (massa corporal $x$ estatura2) como indicador do estado nutricional de adultos: revisão da literatura. Rev Saude Publica 1992; 26: 431-6.

26. Smalley KJ, Knerr NA, Kendrick ZV, Colliver JA, Owen OE. Reassessment of body mass indices. Am J Clin Nutr 1990; 52: 405-8.

27. Forbes GB. The adult decline in lean body mass. Human Biol 1976; 48: 161-73. 
28. Rothman KJ. BMI-related errors in the measurement of obesity. Int J Obes. 2008; 32 (Suppl 3): S56-9.

29. Deurenberg P, Andreoli A, Borg P, Kukkonen-Harjula K, de Lorenzo A, van Marken Lichtenbelt WD et al. The validity of predicted body fat percentage from body mass index and from impedance in samples of five European populations. Eur J Clin Nutr. 2001; 55: 973-9.

30. Jackson AS, Stanforth PR, Gagnon J, Rankinen T, Leon AS, Rao DC et al. The effect of sex, age and race on estimating percentage body fat from body mass index: The Heritage Family Study. Int J Obes Relat Metab Disord. 2002; 26: 789-96.

31. Nevill AM, Stewart AD, Olds T, Holder R. Relationship between adiposity and body size reveals limitations of BMI. Am J Phys Anthropol 2006; 129(1): 151-6.

32. Mialich MS, Martinez EZ, Garcia RWD, Jordao Junior AA. New body mass index adjusted for fat mass (BMIfat) by the use of electrical impedance. Internat J Body Composition Res 2011; 9: 65-72.

33. Yanovski J, Yanovski S, Sovik $K$, Nguyen $T$, Oneil $P$, Sebring N. Holiday weight gain. N Engl J Med 2000; 34: 861-67.

34. American College of Sports Medicine. Position stand. The recommended quantity and quality of exercise for developing and maintaining cardiorespiratory and muscular fitness, and flexibility in health adults. Med Sci Sports Exerc. 1998; 30(6): 1-34.

35. Manson JE, Greenland P, LaCroix AZ, Stefanick ML, Mouton $C P$, Oberman A, et al. A prospective study of walking compared with vigorous exercise in the prevention of coronary heart disease in women. N Engl J Med. 1999; 341(9): 650-8. , 2013. p 114.

36. Instituto Nacional de Estudos e Pesquisas Educacionais Anísio Teixeira. Censo da educação superior: 2011 - resumo técnico. - Brasília: Instituto Nacional de Estudos e Pesquisas Educacionais Anísio Teixeira; tab. ISBN: 978-85-7863022-5. 2013, p 114.

37. Rozmus CL, Evans R, Wysochansky M, Mixon D. An analysis of health promotion and risk behaviors of freshman college students in a rural southern setting. J Pediatr Nurs 2005; 20(1): 25-33.

38. Magoc D, Tomaka J, Thompson S. Overweight, obesity and strong attitudes: predicting participation in physical activity in a predominantly Hispanic college population. Health Education J 2010; 69(4): 427-38.

39. Boyle JR, LaRose NR. Personal beliefs, the environment and college students' exercise and eating behaviors. Am J Health Studies 2009; 23(4): 195-200.

40. Perusse-Lachance E, Tremblay A, Drapeau V. Lifestyle factors and other health measures in a Canadian university community. Applied Physiol, Nutr Metab. 2010; 35(4): 498-506.

41. World Health Oganization. Obesity: Preventing and Managing the Global Epidemic. Report of a WHO Consultation on Obesity. Geneva (WHO technical report series). 1998.

42. Acuña K, Cruz T. Avaliação do estado nutricional de adultos e idosos e situação nutricional da população brasileira. Arq Bras Endocrinol Metab. 2004; 48(3):345-61.

43. WHO Expert Committee on Physical Status: the use and interpretation of Anthropometry Physical status: the use and interpretation of anthropometry: Report of a WHO expert committee. (WHO technical report series; 854) World Health Organization 1995.

44. World Health Oganization. Obesity: preventing and managing the global epidemic. Report of a WHO consultation. World Health Organ Tech Rep Ser. 2000;894:i-xii, 1-253.

45. Yahia N, Achkar A, A bdallah A, Rizk S. Eating habits and obesity among Lebanese university students. Nutr J. 2008; 7(32):1-6.

46. Bertsias G, Mammas I, Linardakis M, Kafatos A: Overweight and obesity in relation to cardiovascular disease risk factors among medical students in Crete, Greece. BMC Public Health 2003; 3(3):1-9.

47. Lowry R, Galuska DA, Fulton JE, Wechsler H, Kann L, Collins JL. Physical activity, food choice, and weight management goals and practices among US college students. Am J Prev Med. 2000; 18(1): 18-27.

48. Heydari ST, Ayatollahi SM, Zare N. Diagnostic value of bioelectrical impedance analysis versus body mass index for detection of obesity among students. Asian J Sports Med. 2011; 2(2): 68-74.

49. Al-Rethaiaa AS, Fahmy AE, Al-Shwaiyat NM. Obesity and eating habits among college students in Saudi Arabia: a cross sectional study. Nutr J. 2010; 9(39): 2-10.

50. Carpenter $C L$, Yan E, Chen $S$, Hong $K$, Arechiga A, Kim WS, Deng M, Li Z, Heber D. Body fat and body-mass index among a multiethnic sample of college-age men and women. J Obes. 2013; 2013: 1-7.

51. American College of Sports Medicine. The recommended quantity and quality of exercise for developing and maintaining cardiorespiratory and muscular fitness, and flexibility in healthy adults. Med Sci Sports Exerc. 1998; 30: 975-91.

52. Pinto BM, Marcus BH. A stage of change approach to understanding college students' physical activity. J Am Coll Health 1995; 44(1): 27-31.

53. Keating XD, Guan J, Piñero JC, Bridges DM. A metaanalysis of college students' physical activity behaviors. J Am Coll Health 2005; 54(2): 116-25.

54. Arnett JJ. Conceptions of the transition to adulthood: Perspectives from adolescence through midlife. J Adult Dev. 2001; 8: 133-43.

55. Racette SB, Deusinger SS, Strube MJ, Highstein GR, Deusinger RH. Weight changes, exercise, and dietary patterns during freshman and sophomore years of college. J Am Coll Health 2005; 53(6): 245-51.

56. Greene GW, Schembre SM, White AA, Hoerr SL, Lohse $B$, Shoff S, Horacek T, Riebe D, Patterson J, Phillips $B W$, Kattelmann $K K$, Blissmer B. Identifying clusters of college students at elevated health risk based on eating and exercise behaviors and psychosocial determinants of body weight. J Am Diet Assoc. 2011; 111(3):394-400.

57. Ferreira I, Twisk JW, van Mechelen W, Kemper HC, Stehouwer CD. Development of fatness, fitness, and lifestyle from adolescence to the age of 36 years: determinants of the metabolic syndrome in young adults: the Amsterdam growth and health longitudinal study. Arch Intern Med. 2005; 165 (1): 42-8.

58. Adams T, Rini A. Predicting 1-year change in body mass index among college students. J Am Coll Health 2007; 55(6): 361-5. 